\title{
Primary genotoxicity in the liver following pulmonary exposure to carbon black nanoparticles in mice
}

\author{
Justyna Modrzynska ${ }^{1,2}$, Trine Berthing², Gitte Ravn-Haren ${ }^{1}$, Nicklas Raun Jacobsen², Ingrid Konow Weydahl², \\ Katrin Loeschner ${ }^{1}$, Alicja Mortensen², Anne Thoustrup Saber ${ }^{2}$ and Ulla Vogel ${ }^{2,3^{*}}$
}

\begin{abstract}
Background: Little is known about the mechanism underlying the genotoxicity observed in the liver following pulmonary exposure to carbon black (CB) nanoparticles (NPs). The genotoxicity could be caused by the presence of translocated particles or by circulating inflammatory mediators released during pulmonary inflammation and acute-phase response. To address this, we evaluated induction of pulmonary inflammation, pulmonary and hepatic acute-phase response and genotoxicity following exposure to titanium dioxide $\left(\mathrm{TiO}_{2}\right)$, cerium oxide $\left(\mathrm{CeO}_{2}\right)$ or CB NPs. Female C57BL/6 mice were exposed by intratracheal instillation, intravenous injection or oral gavage to a single dose of $162 \mu \mathrm{g} \mathrm{NPs} /$ mouse and terminated 1, 28 or 180 days post-exposure alongside vehicle control.

Results: Liver DNA damage assessed by the Comet Assay was observed after intravenous injection and intratracheal instillation of CB NPs but not after exposure to $\mathrm{TiO}_{2}$ or $\mathrm{CeO}_{2}$. Intratracheal exposure to NPs resulted in pulmonary inflammation in terms of increased neutrophils influx for all NPs 1 and 28 days post-exposure. Persistent pulmonary acute phase response was detected for all NPs at all three time points while only a transient induction of hepatic acute phase response was observed. All 3 materials were detected in the liver by enhanced darkfield microscopy up to 180 days post-exposure. In contrast to $\mathrm{TiO}_{2}$ and $\mathrm{CeO}_{2} \mathrm{NPs}, \mathrm{CB} N$ Ps generated ROS in an acellular assay.
\end{abstract}

Conclusions: Our results suggest that the observed hepatic DNA damage following intravenous and intratracheal dosing with CB NPs was caused by the presence of translocated, ROS-generating, particles detected in the liver rather than by the secondary effects of pulmonary inflammation or hepatic acute phase response.

Keywords: Carbon black, Cerium oxide, Titanium dioxide, Nanoparticles, Liver, Intratracheal instillation, Intravenous injection, Oral gavage, Genotoxicity, DNA strand breaks

\section{Background}

The wide range of nanoparticles (NPs) applications leads to increased risk of unintended human exposure for consumers as well as for workers in the occupational environment. Inhaled NPs constitute a potential health risk [1] and therefore, understanding the fate and toxicity

\footnotetext{
*Correspondence: ubv@nrcwe.dk; ubv@arbejdsmiljoforskning.dk

${ }^{2}$ The National Research Centre for the Working Environment, Lersø Parkallé

105, DK-2100 Copenhagen $\varnothing$, Denmark

${ }^{3}$ Department of Micro- and Nanotechnology, Technical University of

Denmark, Kongens Lyngby, Denmark

Full list of author information is available at the end of the article
}

following pulmonary exposure to NPs has become an important issue.

Inhalation of particles leads to size dependent pulmonary deposition [2, 3]. A large fraction of the pulmonary deposited particles is removed from the upper airways by the mucociliary escalator and subsequently swallowed resulting in secondary exposure through the oral route [4-7]. In addition, a small fraction of the pulmonary deposited particles undergo translocation and primarily accumulate in the liver but also in other secondary organs [7-12].

Inhalation and intratracheal instillation of NPs induce pulmonary inflammation which is accompanied by a 
pulmonary acute phase response [13-15]. We have previously shown that instillation and inhalation of $\mathrm{CB}$ Printex 90 NPs induced hepatic genotoxicity in terms of increased DNA strand break levels and increased levels of oxidative DNA damage [14, 16-18]. However, the underlying mechanism is not clear. Exposure to particles can cause primary or secondary genotoxicity. Primary genotoxicity refers to DNA damage caused by direct physical interaction between particles and the genomic DNA and by ROS-mediated DNA damage in the absence of inflammation. Secondary genotoxicity refers to DNA damage as a result of action of reactive oxygen species (ROS) and reactive nitrogen species (RNS) as well as other secondary mediators (cytokines, chemokines) that are generated during particle-induced inflammation and acute phase response in the lungs that could initiate DNA damaging processes in the liver including induction of a hepatic acute phase response $[19,20]$.

The NPs used in this work, i.e. titanium dioxide $\left(\mathrm{TiO}_{2}\right)$, cerium oxide $\left(\mathrm{CeO}_{2}\right)$ and carbon black $(\mathrm{CB})$ are all worldwide-used high-volume nanomaterials. Moreover, CB is a well-known ROS generator [21] and has been shown to be mutagenic [22]. $\mathrm{TiO}_{2}$-induced oxidative stress [23] and genotoxicity $[24,25]$ were also previously reported. In addition, $\mathrm{CeO}_{2}$-mediated DNA damages were confirmed in both in vivo [26] and in vitro [27] studies. CB NPs were included in the study as the DNA damaging test material in liver whereas $\mathrm{TiO}_{2}$ and $\mathrm{CeO}_{2}$ NPs were included as inflammogenic NPs with relatively low ROS generating abilities.

The objective of the present study was to assess the etiology of particle-induced genotoxicity in the liver. We therefore dosed mice with 3 different nanomaterials: $\mathrm{TiO}_{2}, \mathrm{CeO}_{2}$ and $\mathrm{CB}$ by pulmonary, oral and intravenous dosing to determine whether the observed hepatic DNA strand breaks are caused by secondary genotoxicity from pulmonary or hepatic inflammatory and acute phase responses or by direct genotoxicity from translocated NPs. Oral exposure was included to assess the contribution from the secondary oral exposure that accompanies particle clearance by the mucociliary escalator. Intravenous (IV) exposure was included to assess the effect of particle translocation and hepatic accumulation.

\section{Methods}

\section{Animal study}

Three hundred twenty four young adult C57BL/6 (B6JBOM-F) female mice were purchased from Taconic (Ry, Denmark) at 6 weeks of age and body weight of $17.5 \pm 0.9 \mathrm{~g}($ mean $\pm \mathrm{SD})$ and allowed to acclimate for 2 weeks before exposure. All animals were provided with the standard pellet diet (Altromin No. 1324) and acidified water ad libitum and housed in polypropylene cages with bedding and enrichment at controlled temperature
$22 \pm 1{ }^{\circ} \mathrm{C}$ and humidity of $55 \% \pm 5$ and with the reverse $12 \mathrm{~h}$ light/ $12 \mathrm{~h}$ dark cycle. The study was conducted in the agreement with the Danish Animal Experimental Inspectorate under the Ministry of Justice (Permission 2012-15-2934-00089 C6) and the Technical University of Denmark's animal welfare protocol.

\section{Preparation of exposure stock}

$\mathrm{TiO}_{2}$ was provided by NanoAmor, $\mathrm{CeO}_{2}$ was provided by Degussa-Quimidroga and CB (Printex 90) was provided by Evonik Degussa. Physicochemical characteristics of particles are presented in Table 1. All three materials were suspended in $2 \% v / \mathrm{v}$ mouse serum from C57BL/6 mice in nanopure water to a final concentration of $3.24 \mathrm{mg} / \mathrm{ml}$ and dispersed by sonication for 15 min using Microson ultrasonic cell disruptor (XL-2000, Microson ${ }^{\text {Tw}}$, Qsonica, LLC.) equipped with disruptor horn with a diameter of $3.2 \mathrm{~mm}$ and maximum peak-to-peak amplitude of $180 \mu \mathrm{m}$. Suspensions were cooled on ice during the sonication procedure to prevent sample overheating. Control vehicle, $2 \%$ serum in nanopure water, was also sonicated prior to exposure as described above.

Dynamic light scattering (Malvern Zetasizer Nano ZS, Malvern Instruments, UK) was used to determine the hydrodynamic size distribution in the sonicated suspensions before administration. The suspensions were prepared as described above and measured in transparent $1 \mathrm{ml}$ disposable cuvettes at the temperature of $25^{\circ} \mathrm{C}$. Six consecutively repeated measurements were performed. Duration of each measurement as well as attenuator index and measurement position within the cuvette were determined automatically by the instrument. For the calculation of the number-based particle size distribution, refractive index and extinction coefficient (absorption) for the tested materials were as followed: 2.9 and 0.1, respectively, for $\mathrm{TiO}_{2}, 2.2$ and 0.1 , respectively, for $\mathrm{CeO}_{2}$, 2.02 and 2.0, respectively, for CB NPs.

\section{Exposure of mice}

The mice ( $n=9$ per group) were given a single dose of $162 \mu \mathrm{g}$ of $\mathrm{TiO}_{2}, \mathrm{CeO}_{2}$, or CB NPs suspension in a volume of $50 \mu \mathrm{l}$ by intratracheal instillation, intravenous injection and oral gavage. Control mice received $50 \mu \mathrm{l}$ of $2 \%$ serum (in nanopure water) that served as a vehicle for the preparation of NPs suspension. The dose used in the experiment was equal to the pulmonary deposition after nine $8 \mathrm{~h}$ working days at the Danish occupational exposure limit of $3.5 \mathrm{mg} / \mathrm{m}^{3}$ for $\mathrm{CB}$ [14]. Occupational exposure concentrations of up to $15 \mathrm{mg} / \mathrm{m}^{3} \mathrm{CB}$ have been reported and the current dose would correspond to the pulmonary deposition during 2.2 work-days [28]. Mice subjected to intratracheal instillation and intravenous injection were anaesthetized with $0.5 \mathrm{ml} / 100 \mathrm{~g}$ body weight of Hypnorm ${ }^{\bullet}$ (Fentanyl citrate $0.315 \mathrm{mg} / \mathrm{ml}$ and 
Table 1 Selected physicochemical parameters of the tested nanomaterials

\begin{tabular}{llll}
\hline & $\mathrm{TiO}_{2}$ & $\mathrm{CeO}_{2}$ & $\mathrm{CB}$ \\
\hline Source & NanoAmor & Degussa/Quimidroga & Evonik-Degussa \\
Product form & Powder & Powder & Powder \\
Primary particle size & $10.5 \mathrm{~nm}^{\mathrm{b}}$ & $13.0 \pm 12.1 \mathrm{~nm}^{\mathrm{a}}$ & $14 \mathrm{~nm}^{c}$ \\
Specific surface area & $139.1 \mathrm{~m}^{2} / \mathrm{g}^{\mathrm{b}}$ & $56.7 \mathrm{~m}^{2} / \mathrm{g}^{\mathrm{a}}$ & $295 \mathrm{~m}^{2} / \mathrm{g}^{\mathrm{d}}$ \\
Particle density & $4.23 \mathrm{~g} / \mathrm{cm}^{3} \mathrm{e}$ & $7.29 \mathrm{~g} / \mathrm{cm}^{3}$ & $2.1 \mathrm{~g} / \mathrm{cm}^{3} \mathrm{~d}$ \\
\hline
\end{tabular}

${ }^{\mathrm{a}}[62] ;{ }^{\mathrm{b}}[63] ;{ }^{\mathrm{c}}[29] ;{ }^{\mathrm{d}}[64] ;{ }^{\mathrm{e}}[65]$

Fluanisone $10 \mathrm{mg} / \mathrm{ml}$, Nomeco) and Dormicum ${ }^{\circ}$ (Midazolam $5 \mathrm{mg} / \mathrm{ml}$, Roche) by subcutaneous injection in the neck prior the NP administration. Orally gavaged mice were not anaesthetized before the administration. Pulmonary exposed mice were dosed by intratracheal instillation as described previously [29]. In short, the sedated mice devoted for intratracheal instillation were placed on a $40^{\circ}$ slope (upside down, with the head towards the floor) and a diode lamp was placed on the larynx to assure better visualization of the airways. The tongue was pressed down towards the lower jaw using a small spatula. 22 GA BD Insyte catheter (Becton Dickinson, Utah, USA) with a shortened needle used to intubate the trachea. The proper position of each catheter was confirmed by a highly sensitive pressure transducer. In a $250 \mu \mathrm{l} \mathrm{SGE}$ glass syringe (250F-LT-GT, MicroLab, Aarhus, Denmark) a volume of $50 \mu \mathrm{l}$ of NP suspension followed by $200 \mu \mathrm{l}$ air was instilled. Control groups received $50 \mu \mathrm{l}$ of a control vehicle prepared as described above. After the removal of the catheter mice were placed back into vertical position with the head up to assure that the NP suspension remains in the lung and that the airways are unobstructed. We have previously shown the overall and even pulmonary distribution of particles using this exposure technique [30, 31]. Mice devoted for intravenous injection were restrained in plexiglas restraining tubes with the tail hanging out of the tube. Injection was performed using $0.4 \times 20 \mathrm{~mm}$ needle (Terumo Europe, n.v. 3001, Leuven, Belgium). After the exposure, sedated mice were placed back to their cages, heated with a heating lamp and/or warming blanket and monitored until they fully recovered from anesthesia. Mice devoted for oral gavage were immobilized in a vertical position and the gavage needle was inserted into the esophagus and further toward the stomach to release the suspension of particles. After the exposure, mice returned to the cages and were closely monitored.

\section{Necropsy and cells \& tissues collection}

One, 28 and 180 days following administration of NPs mice were sedated by Hypnorm/Dormicum mixture (0.5$0.7 \mathrm{ml} / 100 \mathrm{~g}$ body weight) followed by the exsanguination by withdrawing the heart blood. Abdomen and thorax of mice were opened and macroscopic examination of all organs was performed. All observed abnormalities were noted. After withdrawal of the heart blood in the intratracheally instilled mice bronchoalveolar lavage (BAL) was performed ( $N=6$ mice/group). Lungs were flushed twice through the trachea with $0.8 \mathrm{ml}$ of $0.9 \%$ sterile saline $(\mathrm{NaCl})$ as described [32]. Each flush consisted of 3 up and down movements and was performed slowly (5-10 s each). The BAL was stored on ice until the centrifugation at $400 \mathrm{~g}$ for $10 \mathrm{~min}$ at $4{ }^{\circ} \mathrm{C}$ (Ole Dich centrifuge) was performed. The supernatant, BAL fluid (BALF), was collected in $1.5 \mathrm{ml}$ tubes, snap-frozen in liquid nitrogen and stored at $-80{ }^{\circ} \mathrm{C}$ until used. The BAL cells were re-suspended in $100 \mu \mathrm{l}$ HAMS-F12 medium (HAMS-F12, GIBCO \#21765, with $1 \%$ penicillin/streptomycin and $10 \%$ fetal bovine serum). BAL cells devoted for comet assay were prepared by the following procedure as described [32]: $40 \mu \mathrm{l}$ of the cell suspension was mixed with $60 \mu \mathrm{l}$ of cell culture freezing medium (HAMS-F12 with $1 \%$ penicillin/streptomycin, $10 \%$ fetal bovine serum and $10 \%$ of DMSO), divided into two $50 \mu \mathrm{l}$ aliquots and stored at $-80{ }^{\circ} \mathrm{C}$ until used. The total number of cells presented in the BAL fluid was determined using the Nucleo-Counter NC-100 with NucleoCassette $^{\mathrm{ma}}$ (Chemometec, Allerød, Denmark). $20 \mu \mathrm{l}$ of the cell suspension was mixed with $180 \mu \mathrm{l}$ HAMS F12 medium, suspension was divided into 2 aliquots and live/ dead cells were counted according to the manufacturer's instructions. For the estimation of cellular composition in BAL fluid rest of the cell suspension (approximately $40 \mu \mathrm{l}$ ) was deposited on the microscope slide by centrifugation at room temperature for $10 \mathrm{~min}$. at $550 \mathrm{~g}$ in a Cytofuge 2 (StatSpin, TRIOLAB, Brønby, Denmark). The slides were fixed in $96 \%$ ethanol for $5 \mathrm{~min}$ and stained with MayGrünwald-Giemsa dye using standard staining protocol. The cellular composition was quantified on 200 cells under light microscope (100 x magnifications). The liver ( $N=9$ /group) and lungs (from BAL flushed mice, $N=6 /$ group) were divided into specific pieces, snap frozen in liquid nitrogen in cryotubes (NUNC) and stored at $-80{ }^{\circ} \mathrm{C}$ for later use. For all mice throughout the whole experiment samples were taken from the same parts of organs. Specimens from livers ( $\mathrm{N}=9$ /group) and lungs (from mice that had not been used for BALF collection, $N=3$ /group) were fixed in $4 \%$ neutral buffered formaldehyde, paraffinembedded and $4 \mu \mathrm{m}$ thick sections were stained with hematoxylin and eosin for microscopical examination. 


\section{Brightfield and darkfield microscopy}

Cytoviva enhanced darkfield hyperspectral system (Auburn, AL, USA) was used to detect particles in the liver tissue, by scanning histological sections at $40 \mathrm{x}$ in enhanced darkfield mode. Darkfield images were acquired at $40 \mathrm{x}$ and brightfield images were acquired at $40 \times$ and $100 \mathrm{x}$ on an Olympus BX 43 microscope with a Qimaging Retiga4000R camera. Uneven illumination in brightfield images was corrected using ImageJ [33] and the Calculator Plus plugin via the formula: Corrected_image $=($ image $/$ background $)$ * 255 . The background image was a maximum projection of 3 background brightfield images without tissue.

\section{Preparation of mRNA and cDNA from the liver and lung tissue}

Total RNA was isolated from the frozen liver and lung tissue (16-20 mg) on Maxwell 16 (Promega,

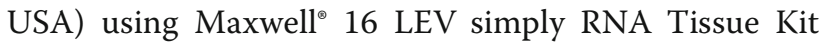
(AS1280, Promega, USA) following the manufacturer's protocol. Tissue lysis was performed by vigorously shaking the samples using a Tissuelyser (Qiagen, Denmark) with a $5 \mathrm{~mm}$ stainless steel beads for $60 \mathrm{~s}$. DEPC-treated nuclease-free water was used to elute the mRNA. Complementary DNA (cDNA) was prepared using TaqMan $^{\oplus}$ reverse transcription reagents (Applied Biosystem, USA) as stated in manufacturer's protocol. Concentration of total mRNA was determined by NanoDrop 2000c (ThermoFisher, USA).

\section{Real-time RT-PCR}

Gene expression levels of Saa1 in the liver tissue and Saa3 in the lung tissue were assessed using quantitative PCR as described previously [25, 34]. 18S RNA served as a reference gene. Each of the analyzed samples was run in triplicates using ViiA7 Real-Time PCR detector (Applied Biosystem, USA). TaqMan ${ }^{\odot}$ predeveloped reagents were used throughout the analysis. Target and reference gene expression was quantified in triplicates in separate wells. Target gene expression was determined by the comparative method $2^{-\Delta \mathrm{Ct}}$.

\section{Comet assay}

DNA strand break levels were quantified by the comet assay in the liver and lung tissue and BAL cells as described in [35]. In brief, single-cell suspension of the liver and lung tissue was obtained by the homogenization of the deep frozen liver and lung piece in an ice-cold Merchant's buffer through a stainless steel mesh (diameter $0.5 \mathrm{~cm}$, mesh size $0.4 \mathrm{~mm}$ ) mounted on a syringe, to yield individual cells. The BAL fluid cells were thawed in a $37^{\circ}$ $\mathrm{C}$ water bath before diluting with the Mechant's buffer without the filtration step. The cell suspension was embedded in a low melting point agarose $(0.7 \%)$ and deposited on microscope Travigen 20-Well CometSlides ${ }^{\mathrm{Tm}}$. The slides were immersed in a lysing solution and stored overnight at $4{ }^{\circ} \mathrm{C}$. Subsequently, samples were treated with an alkaline buffer and alkaline electrophoresis with circulating ice-cold electrophoresis buffer was performed (25 min, $38 \mathrm{~V} / \mathrm{cm}, 0.700 \mathrm{~A}$ ). Thereafter, slides were neutralized in neutralization buffer $(0.4 \mathrm{M}$ Tris, $\mathrm{pH} 7.5)$, fixed with $96 \%$ ethanol and stained with a fluorescent DNA intercalating dye SYBRGreen ${ }^{\circ}$. DNA strand breaks determined as the \% of DNA in the comet tail (\%TDNA) and as the comet tail length (TL) were scored by the fully automated PatchFinder ${ }^{\mathrm{Tm}}$ system (IMSTAR, France). In order to control the day-to-day variation and to ensure equal electrophoresis efficiency both negative (A549 human lung epithelial cell line treated with PBS for $30 \mathrm{~min}$ at $4^{\circ}$ C) and positive (A549 human lung epithelial cell line treated with $60 \mu \mathrm{M} \mathrm{H} \mathrm{H}_{2} \mathrm{O}_{2}$ for $30 \mathrm{~min}$ at $4{ }^{\circ} \mathrm{C}$,) controls were included. The high throughput comet assay analysis allowed analysis of all related sample on the same day decreasing potential variation due to the different electrophoresis or the duration of the incubation procedure.

\section{Determination of ROS-generating ability of NPs}

Assessment of NPs ability to generate ROS was performed in vitro in a cell-free environment as described

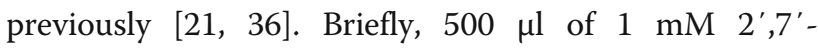
dichlorodihydrofluorescein diacetate $\left(\mathrm{DCFH}_{2}\right.$-DA) (Invitrogen) was chemically hydrolyzed with $2 \mathrm{ml}$ of $0.01 \mathrm{M}$ $\mathrm{NaOH}$ for $30 \mathrm{~min}$ to $2^{\prime}, 7^{\prime}$-dichlorodihydrofluorescein $\left(\mathrm{DCFH}_{2}\right) \cdot \mathrm{DCFH}_{2}$-DA probe is light sensitive therefore the experiment was conducted in a dark environment. The formed $\mathrm{DCFH}_{2}$ was further diluted with $10 \mathrm{ml}$ of $25 \mathrm{mM}$ phosphate buffer ( $\mathrm{pH}$ 7.4) to $0.04 \mathrm{mM}$. The NPs' ability to generate ROS production was determined in Hank's balanced saline solution (HBSS, without phenol) using a final $\mathrm{DCFH}_{2}$ concentration of $0.01 \mathrm{mM}$. Prior to the assay, NPs were sonicated (Branson S-450D) for 16 min without a pause and further diluted in HBSS. Generated ROS caused formation of $2^{\prime}, 7^{\prime}$-dichlorofluorescein (DCF) from $\mathrm{DCFH}_{2}$ that was spectrofluorimetrically measured following $3 \mathrm{~h}$ of incubation in the dark $\left(37{ }^{\circ} \mathrm{C}\right.$ and $\left.5 \% \mathrm{CO}_{2}\right)$. Excitation and emission wavelengths were $\lambda_{\mathrm{ex}}=490 \mathrm{~nm}$ and $\lambda_{\mathrm{em}}=520 \mathrm{~nm}$, respectively (Victor Wallac-2 1420; PerkinElmer, Skovlunde, Denmark).

\section{Statistical analysis}

All presented values are expressed as mean \pm standard deviation (SD) unless differently stated. One-way or twoway analysis of variance (ANOVA) was used to analyze the data sets. In order to fulfil the normality and variance homogeneity criteria some variables were logarithmically transformed. Non-normally distributed data were ranked before applying nonparametric one-way or two-way ANOVA analysis. If the statistical significance 
was reached in the ANOVA analysis, Tukey post-hoc multiple comparison test was used to test the differences between the test groups. $P$-value $\leq 0.05$ was considered significant. All statistical analyses were calculated using SAS 9.4 statistical software (SAS Institute Inc., Cary, NC, USA).

\section{Results}

\section{DLS}

Dynamic light scattering (DLS) was used to determine particle agglomerate size of $\mathrm{TiO}_{2}, \mathrm{CeO}_{2}$ and $\mathrm{CB}$ NPs suspensions. The both the hydrodynamic number-based size distribution revealed a narrow, unimodal peak with the average diameter below $100 \mathrm{~nm}$ for all particle suspensions (Fig. 1). The intensity size distributions also showed unimodal peaks (Fig. 1). The median particle diameter measured for $\mathrm{TiO}_{2}, \mathrm{CeO}_{2}$ and CB NPs was $68 \mathrm{~nm}, 68 \mathrm{~nm}$, and $51 \mathrm{~nm}$, respectively. Z-average and polydispersity index were 131.4 and 0.120 , respectively, for $\mathrm{TiO}_{2}, 148.8$ and 0.174 , respectively, for $\mathrm{CeO}_{2}, 104.3$ and 0.157 , respectively, for CB NPs.

\section{BAL fluid cellular composition}

Analysis of BAL fluid cellular composition following pulmonary exposure to the NPs revealed that intratracheal instillation of all three particles resulted in increased numbers of total cell counts after day 1 as well as increased neutrophil influx in lungs 1 and 28 days postexposure (Fig. 2 and Table 2). Elevation in number of total cell counts after day 1 as well as increased number of neutrophils at day 1 and day 28 is consistent with previous studies [29, 37, 38]. The distributions of total cells, neutrophils, macrophages, lymphocytes, eosinophils are shown in Table 2.

\section{Saa3 mRNA expression in the lung tissue}

Pulmonary acute phase response was assessed as Saa3 mRNA expression levels $[39,40]$. Analysis of Saa3 gene

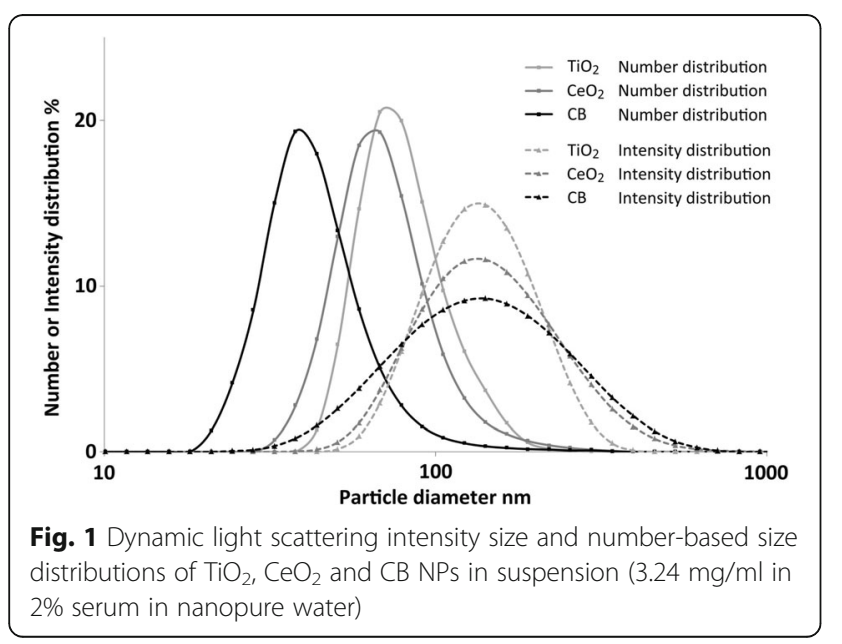

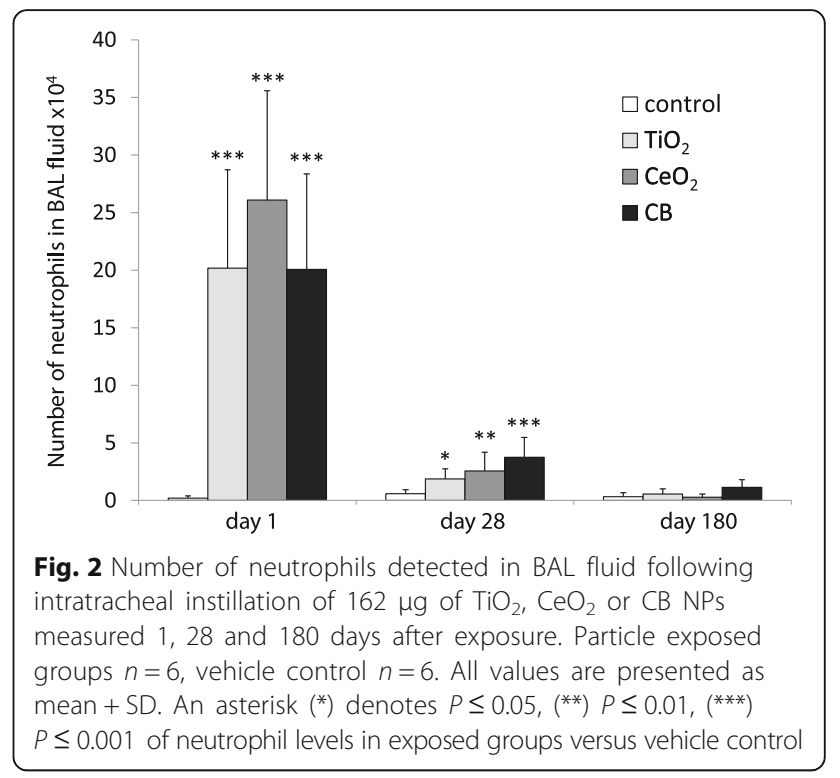

expression revealed acute phase response in the lungs following intratracheal instillation of $\mathrm{TiO}_{2}, \mathrm{CeO}_{2}$ and $\mathrm{CB}$ NPs at all three time points. After day 1 and day 28, pulmonary Saa 3 mRNA levels were statistically significantly increased compared to the vehicle control for all three particles $(P \leq 0.001)$ with no differences between particles. After day 180, pulmonary Saa3 mRNA levels were statistically significantly increased for $\mathrm{TiO}_{2}(P \leq 0.01)$ and $\mathrm{CB}(P \leq 0.001)$ groups with no observed differences between particles (Fig. 3 and Additional file 1).

Overall, our results indicate that pulmonary exposure to all three NPs induces pulmonary inflammation and pulmonary acute phase response.

\section{Hepatic presence of NPs}

Hepatic detection of NPs 180 days after intravenous injection and intratracheal instillation by enhanced darkfield microscopy and brightfield microscopy is presented in Fig. 4. Aggregates of foreign material, visible as white spots were present in liver tissue from mice exposed to $\mathrm{TiO}_{2}$ and $\mathrm{CeO}_{2}$ NPs (Fig. 4B and C, selected NPs marked with white arrowheads). In the livers from mice exposed to CB NPs, black aggregates of foreign material were present (Fig. 4D, selected NPs marked with black arrowheads). Following IT exposure (Fig. 4B-D, panel 2) foreign material aggregates were smaller and much less frequent than aggregates detected in the liver tissue after IV exposure (Fig. B-D, panel 1). In all exposure groups aggregates were primarily detected in sinusoids and partly perivascular and often appeared to be phagocytized by Kupffer cells. Black or white spots were occasionally also seen in vehicle controls, but the appearance and location indicated artefacts from tissue preparation. 
Table 2 BAL fluid cellular composition following intratracheal instillation of $162 \mu \mathrm{g}$ of $\mathrm{TiO}_{2}, \mathrm{CeO}_{2}$ or CB NPs 1, 28 and 180 days post-exposure

\begin{tabular}{|c|c|c|c|c|}
\hline \multicolumn{5}{|c|}{ BAL fluid cellular composition after day 1} \\
\hline & Control & $\mathrm{TiO}_{2}$ & $\mathrm{CeO}_{2}$ & $C B$ \\
\hline Total cells $\left(\times 10^{5}\right)$ & $0.9 \pm 0.6$ & $2.5 \pm 0.9^{* *}$ & $3.4 \pm 1.1^{* * *}$ & $2.4 \pm 1.0^{* *}$ \\
\hline Neutrophils $\left(\times 10^{4}\right)$ & $0.2 \pm 0.2$ & $20.2 \pm 8.5^{* * *}$ & $26.1 \pm 9.5^{* * *}$ & $20.1 \pm 8.3^{* * *}$ \\
\hline Macrophages $\left(\times 10^{4}\right)$ & $9.0 \pm 5.7$ & $4.5 \pm 1.9$ & $6.1 \pm 1.5$ & $2.9 \pm 1.5^{* *}$ \\
\hline Lymphocytes $\left(\times 10^{2}\right)$ & $1.9 \pm 2.9$ & $0.0 \pm 0.0$ & $7.1 \pm 7.9$ & $0.0 \pm 0.0$ \\
\hline Eosinophils $\left(\times 10^{3}\right)$ & $0.0 \pm 0.1$ & $3.0 \pm 2.5^{* *}$ & $13.3 \pm 9.2^{* * *}$ & $7.6 \pm 6.8^{* *}$ \\
\hline \multicolumn{5}{|c|}{ BAL fluid cellular composition after day 28} \\
\hline & Control & $\mathrm{TiO}_{2}$ & $\mathrm{CeO}_{2}$ & $C B$ \\
\hline Total cells $\left(\times 10^{5}\right)$ & $1.4 \pm 0.5$ & $1.1 \pm 0.2$ & $1.6 \pm 0.7$ & $1.6 \pm 0.8$ \\
\hline Neutrophils $\left(\times 10^{4}\right)$ & $0.6 \pm 0.3$ & $1.9 \pm 0.9^{*}$ & $2.6 \pm 1.6^{* *}$ & $3.8 \pm 1.7^{* * *}$ \\
\hline Macrophages $\left(\times 10^{4}\right)$ & $7.9 \pm 2.0$ & $9.3 \pm 2.3$ & $12.9 \pm 5.5$ & $11.9 \pm 5.5$ \\
\hline Lymphocytes $\left(\times 10^{2}\right)$ & $8.5 \pm 13.7$ & $35.5 \pm 44.3$ & $28.3 \pm 55.4$ & $53.7 \pm 78.1$ \\
\hline Eosinophils $\left(\times 10^{3}\right)$ & $51.2 \pm 39.3$ & $0.1 \pm 0.2^{* *}$ & $0.2 \pm 0.3^{*}$ & $0.0 \pm 0.0^{* * *}$ \\
\hline \multicolumn{5}{|c|}{ BAL fluid cellular composition after day 180} \\
\hline & Control & $\mathrm{TiO}_{2}$ & $\mathrm{CeO}_{2}$ & $\mathrm{CB}$ \\
\hline Total cells $\left(\times 10^{5}\right)$ & $0.7 \pm 0.3$ & $1.0 \pm 0.2$ & $0.9 \pm 0.3$ & $1.3 \pm 0.6$ \\
\hline Neutrophils $\left(\times 10^{4}\right)$ & $0.3 \pm 0.4$ & $0.6 \pm 0.4$ & $0.3 \pm 0.3$ & $1.1 \pm 0.7$ \\
\hline Macrophages $\left(\times 10^{4}\right)$ & $7.0 \pm 2.9$ & $9.4 \pm 2.1$ & $8.4 \pm 2.9$ & $11.9 \pm 4.9$ \\
\hline Lymphocytes $\left(\times 10^{2}\right)$ & $0.0 \pm 0.0$ & $0.0 \pm 0.0$ & $0.5 \pm 1.1$ & $0.0 \pm 0.0$ \\
\hline Eosinophils $\left(\times 10^{3}\right)$ & $0.3 \pm 0.4$ & $0.4 \pm 0.5$ & $4.9 \pm 6.8$ & $4.9 \pm 4.4$ \\
\hline
\end{tabular}

Particle exposed groups $n=6$, vehicle control $n=6$. All values are presented as mean \pm SD. An asterisk $(*)$ denotes $P \leq 0.05,(* *) P \leq 0.01,\left({ }^{* * *}\right) P \leq 0.001$ of statistically significantly different cells level in exposed groups versus vehicle control

No exposure related foreign material aggregates were identified following oral exposure (results not shown.)

\section{Saa1 mRNA expression in liver tissue}

Hepatic acute phase response was assessed by the measurement of Saa1 mRNA expression levels [39]. Analysis

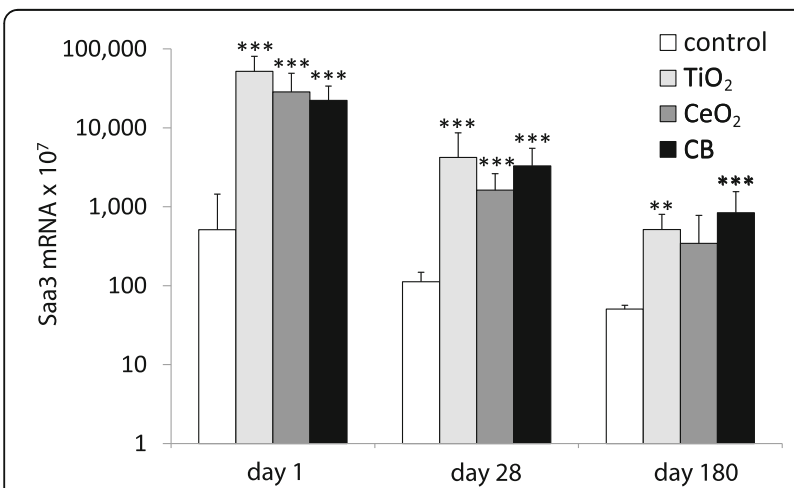

Fig. 3 Pulmonary Saa3 mRNA expression levels in mice following intratracheal instillation of $162 \mu \mathrm{g}$ of $\mathrm{TiO}_{2}, \mathrm{CeO}_{2}$ or CB NPs measured 1,28 and 180 days after the exposure. Saa3 mRNA levels were normalized to $18 \mathrm{~S}$ rRNA. Particle exposed groups $n=6$, vehicle control $n=6$. All values are presented as mean + SD. Asterisks $(* *)$ denote $P \leq 0.01$, $\left(^{* *}\right) P \leq 0.001$ of Saa3 mRNA level in exposed groups versus vehicle control of Saa1 gene expression revealed hepatic acute phase response on day 1 following intratracheal instillation and intravenous injection (Fig. 5 and Additional file 2). No NP-related effects on hepatic Saa1 expression levels were observed at later time points.

One day following intratracheal instillation, hepatic Saa1 mRNA levels were statistically significantly increased for $\mathrm{TiO}_{2}(P \leq 0.01)$ and $\mathrm{CeO}_{2}(P \leq 0.001)$ exposed groups as compared to the vehicle control. $\mathrm{CeO}_{2}$ NPs exposure induced statistically significant higher hepatic Saal mRNA levels than $\mathrm{TiO}_{2}(P \leq 0.05)$ and $\mathrm{CB}(P \leq 0.001)$.

One day following intravenous injection, hepatic Saa1 mRNA level was statistically significantly increased for $\mathrm{TiO}_{2}$ exposed mice compared to the vehicle control $(P \leq 0.01) . \mathrm{TiO}_{2}$ exposure induced statistically significantly higher hepatic Saa1 mRNA levels compared to $\mathrm{CeO}_{2}(\mathrm{P} \leq 0.001)$ and $\mathrm{CB}(P \leq 0.05)$ exposure.

\section{DNA strand breaks in liver and lung}

DNA strand break levels were determined in the liver and lung tissue as well as in the BAL cells using comet assay (Tables 3 and 4 and Figs. 6 and 7).

In the pulmonary exposed groups DNA strand break levels in the liver tissue expressed as \% tail DNA (\%TDNA) were statistically significantly increased compared to the 


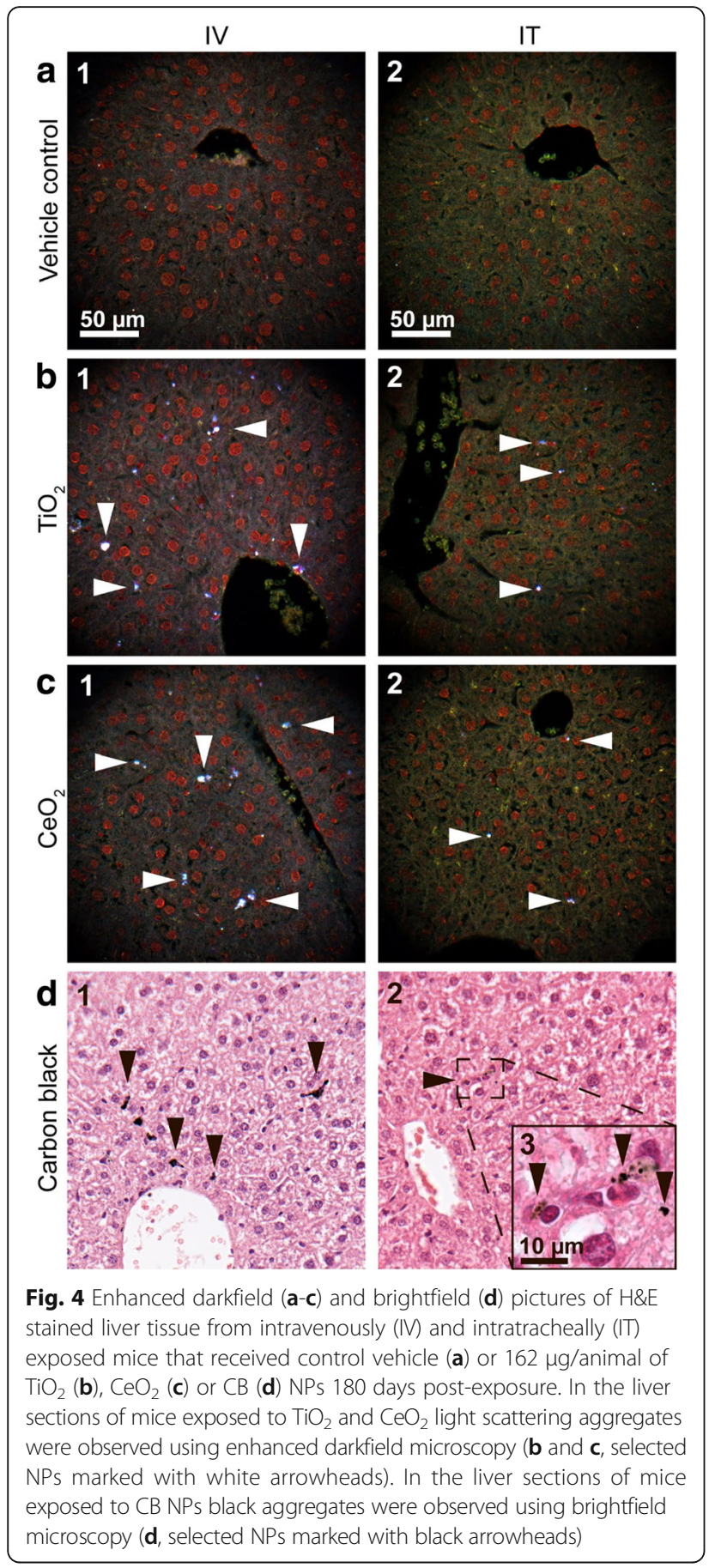

vehicle control in the $\mathrm{CB}$ group (3.2 fold increase, $P \leq 0.01) 28$ days following exposure (Fig. 6). CB exposure also induced statistically significantly higher DNA strand break levels than $\mathrm{TiO}_{2}$ exposure (3.2 fold, $P \leq 0.01$ ). 180 days after intratracheal instillation \%TDNA was statistically significantly increased for $\mathrm{CB}$ exposed group compared to vehicle control (3.8 fold, $P \leq 0.001$ ), $\mathrm{TiO}_{2}$ (3.9 fold, $P \leq 0.001$ ) and $\mathrm{CeO}_{2}$ (2.4 fold, $P \leq 0.05$ ) (Fig. 6 and Table 3).

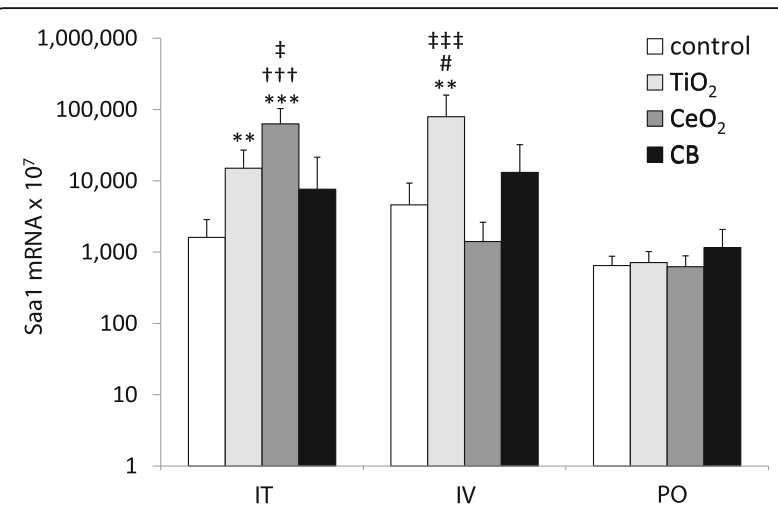

Fig. 5 Hepatic Saa1 mRNA expression levels in mice following intratracheal instillation (I.T.), intravenous injection (I.V.) and oral gavage (P.O.) of $162 \mu \mathrm{g}$ of $\mathrm{TiO}_{2}, \mathrm{CeO}_{2}$ or $\mathrm{CB}$ measured 1 day after exposure. Particle exposed groups $n=9$, vehicle control $n=9$. All values are presented as mean $+\mathrm{SD}$. Asterisks $\left({ }^{* *}\right)$ denote $P \leq 0.01$ and $(* * *) P \leq 0.001$ of Saa 1 mRNA levels in exposed groups versus vehicle control. Hashtag (\#) denotes $P \leq 0.05$ of Saal mRNA level in $\mathrm{TiO}_{2}$ vs $\mathrm{CB}$ groups. Crosses (†+†) denote $\mathrm{P} \leq 0.001$ of Saa 1 mRNA level in $\mathrm{CeO}_{2}$ vs $\mathrm{CB}$ groups. Double cross ( $\neq$ ) denotes $P \leq 0.05$ and

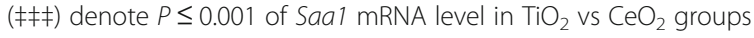

Analysis of the \%TDNA in liver tissue in intravenously exposed groups revealed statistically significantly differences between $\mathrm{CB}$ and vehicle control and between $\mathrm{CB}$ and $\mathrm{TiO}_{2}$ and $\mathrm{CeO}_{2}$ exposed groups (5.8, 5.9 and 4.8 fold increase, respectively, $P \leq 0.0001$ for all groups)

Table 3 DNA strand break levels (\% tail DNA) in liver tissue following intratracheal instillation, intravenous injection and oral gavage of $162 \mu \mathrm{g}$ of $\mathrm{TiO}_{2}, \mathrm{CeO}_{2}$ or CB NPs 1, 28 and 180 days after the exposure determined by the Comet assay

DNA SB in the liver following intratracheal instillation

$\begin{array}{lllll} & \text { Control } & \mathrm{TiO}_{2} & \mathrm{CeO}_{2} & \mathrm{CB} \\ \text { day } 1 & 4.1 \pm 4.6 & 4.3 \pm 1.5 & 3.7 \pm 1.4 & 5.6 \pm 3.7 \\ \text { day } 28 & 3.0 \pm 1.4 & 2.9 \pm 0.8 & 5.2 \pm 5.9 & 9.4 \pm 7.2^{* \text { \#\# }} \\ \text { day } 180 & 3.5 \pm 0.8 & 3.4 \pm 1.0 & 5.5 \pm 2.4 & 12.2 \pm 8.7^{* * \text { *\#\#+ }}\end{array}$

DNA SB in the liver following intravenous injection

$\begin{array}{lllll} & \text { Control } & \mathrm{TiO}_{2} & \mathrm{CeO}_{2} & \mathrm{CB} \\ \text { day } 1 & 3.1 \pm 0.9 & 3.0 \pm 1.0 & 3.7 \pm 1.1 & 17.9 \pm 7.9^{* * * \# \#++\dagger} \\ \text { day } 28 & 5.2 \pm 4.0 & 3.6 \pm 1.1 & 9.7 \pm 4.9 & 16.1 \pm 10.2^{* * * \# \#} \\ \text { day } 180 & 3.3 \pm 0.7 & 5.8 \pm 7.2 & 3.7 \pm 2.0 & 22.8 \pm 11.1^{* * * \# \#++\dagger}\end{array}$

DNA SB in the liver following oral gavage

$\begin{array}{lllll} & \text { Control } & \mathrm{TiO}_{2} & \mathrm{CeO}_{2} & \mathrm{CB} \\ \text { day } 1 & 5.5 \pm 3.8 & 4.6 \pm 3.5 & 7.9 \pm 8.6 & 13.9 \pm 10.4 \\ \text { day } 28 & 3.0 \pm 0.6 & 2.8 \pm 0.6 & 3.3 \pm 0.7 & 2.4 \pm 0.6 \\ \text { day } 180 & 2.8 \pm 0.8 & 3.5 \pm 0.9 & 3.8 \pm 3.5 & 7.2 \pm 6.5\end{array}$

Particle exposed groups $n=9$, vehicle control $n=9$. All values are presented as mean \pm SD. Asterisks $\left(^{* *}\right)$ denote $P \leq 0.01,(* * *) P \leq 0.001$ of DNA SB levels in exposed groups versus vehicle control. Hashtags (\#\#) denote $P \leq 0.01$ and (\#\#\#) $P \leq 0.001$ of DNA SB levels in the $\mathrm{CB}$ groups compared to $\mathrm{TiO}_{2}$ groups. Cross ( $\dagger$ ) denotes $P \leq 0.05$, (†t+) $P \leq 0.001$ of DNA SB levels in the CB groups compared to $\mathrm{CeO}_{2}$ groups 
Table 4 DNA strand break levels (\% tail DNA) in lung tissue 1, 28 and 180 days following intratracheal instillation and from the BAL cells 1 and 28 days following intratracheal instillation of $162 \mu \mathrm{g}$ of $\mathrm{TiO}_{2}, \mathrm{CeO}_{2}$ or $\mathrm{CB}$ determined by the Comet assay

DNA SB in the lungs following intratracheal instillation

$\begin{array}{lllll} & \text { Control } & \mathrm{TiO}_{2} & \mathrm{CeO}_{2} & \mathrm{CB} \\ \text { day } 1 & 3.3 \pm 0.8 & 3.2 \pm 0.9 & 3.8 \pm 0.6 & 4.6 \pm 1.0 \\ \text { day } 28 & 6.1 \pm 1.3 & 5.9 \pm 0.9 & 5.5 \pm 1.1 & 5.3 \pm 1.2 \\ \text { day } 180 & 3.6 \pm 1.0 & 5.2 \pm 0.9^{*} & 4.2 \pm 1.1 & 5.1 \pm 1.4\end{array}$

DNA SB in the BAL cells following intratracheal instillation

$\begin{array}{lllll} & \text { Control } & \mathrm{TiO}_{2} & \mathrm{CeO}_{2} & \mathrm{CB} \\ \text { day } 1 & 4.5 \pm 0.7 & 4.4 \pm 0.9 & 5.6 \pm 1.3 & 5.8 \pm 1.2 \\ \text { day } 28 & 5.9 \pm 1.1 & 4.0 \pm 1.0 & 4.3 \pm 1.0 & 4.0 \pm 1.4\end{array}$

Particle exposed groups $n=6$, vehicle control $n=6$. All values are presented as mean \pm SD. An asterisk $\left(^{*}\right)$ denotes $P \leq 0.05$ of DNA SB levels in exposed groups versus vehicle control

1 day following intravenous injection (Fig. 7). 28 days post-exposure, DNA strand break levels in liver tissue in the $\mathrm{CB}$ group were statistically significantly increased compared to vehicle control (3.1 fold, $P \leq 0.001$ ) and $\mathrm{TiO}_{2}$ exposed group (4.4 fold, $\mathrm{P} \leq 0.0001$ ). 180 days following exposure, DNA strand break levels in liver tissue in the $\mathrm{CB}$ group were statistically significantly increased compared to vehicle control and $\mathrm{TiO}_{2}$ and $\mathrm{CeO}_{2}$ exposed groups $(6.9,4.0$ and 6.2 fold, respectively, $P \leq 0.0001$ for all groups) (Table 3 and Fig. 7).

In the orally exposed groups \%TDNA levels the liver tissue were unaffected by exposure at all assessed time points (Table 3).

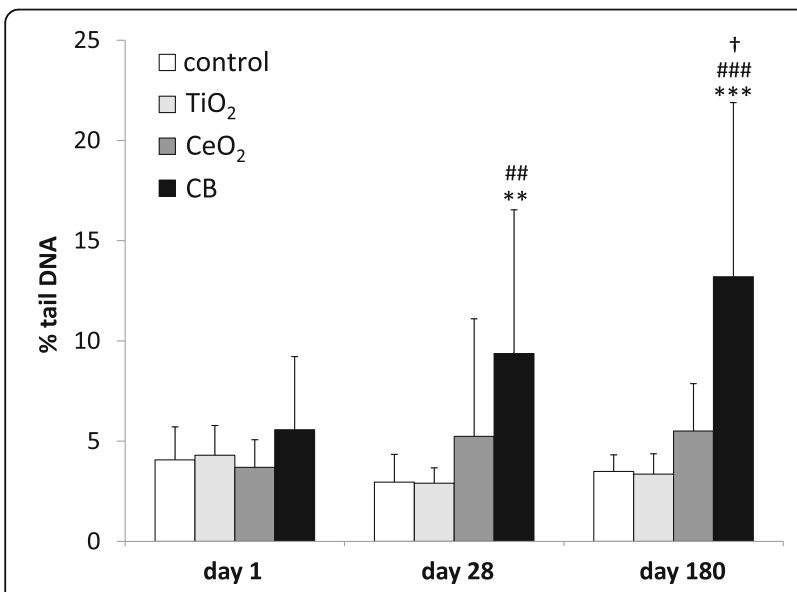

Fig. 6 DNA strand break levels in the liver tissue (\% tail DNA) detected by comet assay following intratracheal instillation of $162 \mu \mathrm{g}$ of $\mathrm{TiO}_{2}, \mathrm{CeO}_{2}, \mathrm{CB}$ measured 1,28 and 180 days after exposure. Particle exposed groups $n=9$, vehicle control $n=9$. All values are presented as mean $+\mathrm{SD}$. Asterisks ${ }^{* *}$ ) denote $P \leq 0.01$, $\left(^{* * *}\right)$ denote $P \leq 0.001$ of DNA SB level in exposed groups versus vehicle control. Hashtags (\#\#) denote $P \leq 0.01$, (\#\#\#) denote $P \leq$ 0.001 of DNA SB level in $\mathrm{TiO}_{2}$ vs CB groups. Cross ( + ) denotes $P \leq$ 0.05 of DNA SB level in $\mathrm{CeO}_{2}$ vs $\mathrm{CB}$ groups

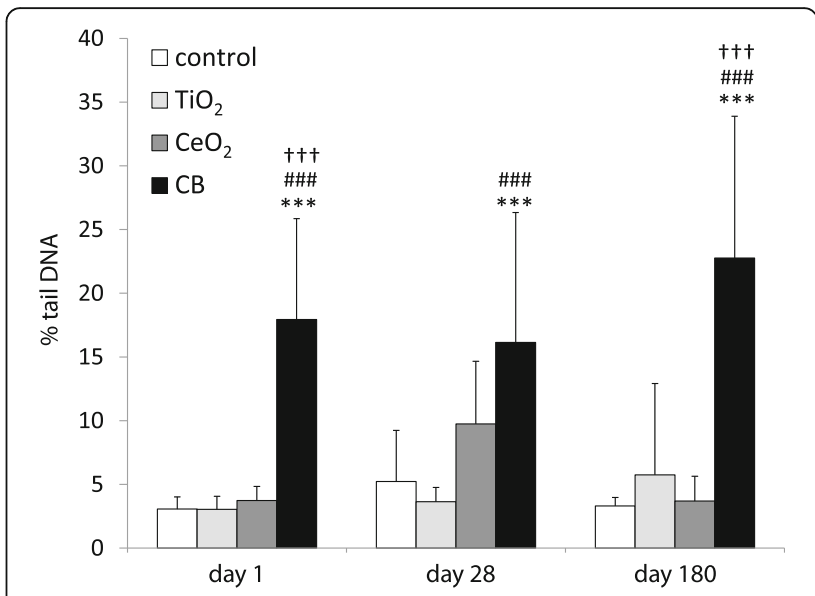

Fig. 7 DNA strand break levels in the liver tissue (\% tail DNA) detected by comet assay following intravenous injection of $162 \mu \mathrm{g}$ of $\mathrm{TiO}_{2}, \mathrm{CeO}_{2}$ or $\mathrm{CB}$ NPs measured 1,28 and 180 days after exposure. Particle exposed groups $n=9$, vehicle control $n=9$. All values are presented as mean $+\mathrm{SD}$. Asterisks $\left.{ }^{(* * *}\right)$ denote $P \leq 0.001$ of DNA SB level in exposed groups versus vehicle control. Hashtags (\#\#\#) denote $P \leq 0.001$ of DNA SB level in $\mathrm{TiO}_{2}$ vs $\mathrm{CB}$ groups. Crosses (†+†) denote $P \leq 0.001$ of DNA SB level in $\mathrm{CeO}_{2}$ vs $C B$ groups

In the lung tissue after intratracheal instillation \%TDNA was unaffected by the exposure after day 1 and day 28 whereas significant increase in \%TDNA was measured in $\mathrm{TiO}_{2}$ group compared to vehicle control (1.5 fold increase, $P \leq 0.05) 180$ days post instillation (Table 4). In the BAL cells \%TDNA was unaffected by the exposure after day 1 and day 28 (Table 4). DNA strand breaks in the BAL cells 180 days following exposure were not analyzed as the samples were lost.

\section{ROS-generation assay}

Among analyzed NPs, CB exhibited the greatest ability to generate ROS (Fig. 8). $\mathrm{CeO}_{2} \mathrm{NPs}$ also generated ROS but the level was negligible and only marginally elevated

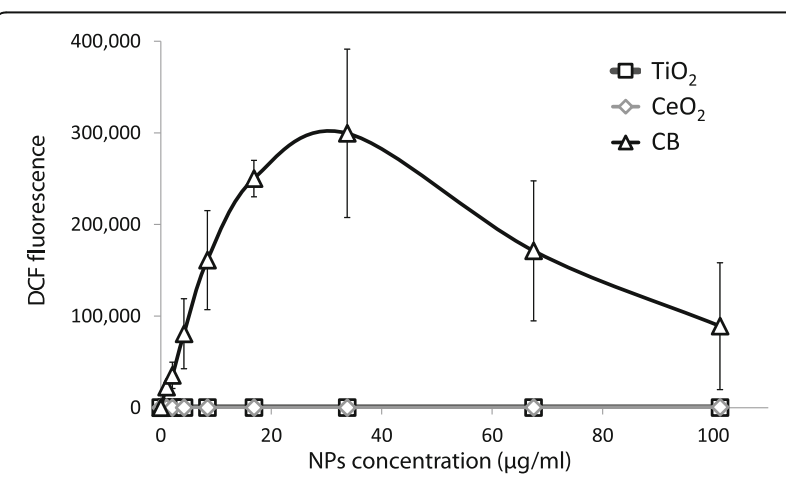

Fig. 8 NPs-induced generation of reactive oxygen species (ROS) measured in a cell-free assay. All values are presented as mean +/SD from 3 independent measurements 
above background. There was no signal detected for $\mathrm{TiO}_{2}$ at any of the analyzed concentrations.

\section{Discussion}

We have previously observed that pulmonary exposure to reactive NPs induced genotoxicity in the liver tissue $[14,17,25,41]$. Therefore, in the present work, we wanted to determine whether the observed hepatic DNA strand breaks following pulmonary exposure to CB NPs were caused by primary genotoxicity due to the direct effects of translocated particles and their ability to induce reactive oxygen species formation [21] or by secondary genotoxicity caused by pulmonary inflammation and acute phase response triggering molecular signaling cascade (release of cytokines, chemokines and ROS/ RNS) that, in turn, initiate downstream toxic effects in the liver $[41,42]$.

\section{Hepatic genotoxicity and possible mechanism for the adverse hepatic effects}

We found evidence of particle translocation from lung to liver for all three NPs using darkfield and brigthfield microscopy. In relation to the current study, we have also quantified the extrapulmonary translocation of $\mathrm{CeO}_{2}$ and $\mathrm{TiO}_{2} \mathrm{NPs}$ following intratracheal exposure using inductively coupled plasma mass spectrometry (ICP-MS) and confirmed translocation of $\mathrm{CeO}_{2}$ and $\mathrm{TiO}_{2}$ to the liver (Modrzynska et al., submitted for publication).

In the present study, intravenous injection of CB NPs resulted in increased DNA strand break (SB) levels in liver 1,28 and 180 days post-exposure, whereas intratracheal instillation of CB induced DNA SBs in liver 28 and 180 days post-exposure. Significant translocation of $\mathrm{TiO}_{2}$ NPs from lung to liver was recently demonstrated using radioactively labelled $\mathrm{TiO}_{2}$ NPs [7]. In agreement with this, we also detected intratracheally instilled $\mathrm{TiO}_{2}$ and $\mathrm{CeO}_{2} \mathrm{NPs}$ in the liver 180 days post-exposure by darkfield microscopy. The fact that hepatic genotoxicity was only observed at the later time points following pulmonary exposure might reflect the time needed for particles to translocate in sufficient amounts from lungs to the liver [7].

It has been previously suggested by Jackson [41] that the observed liver DNA SBs could be a result of gastrointestinal tract exposure due to the whole-body inhalation and further fur grooming. Minute uptake of $\mathrm{TiO}_{2}$ NPs following oral exposure has been reported [7, 43, 44] and it was recently estimated that up to $20 \%$ of $\mathrm{TiO}_{2}$ NPs accumulated in liver following pulmonary exposure had reached the liver by the oral route [7]. However, we have found no detectable translocation of $\mathrm{CeO}_{2}$ and $\mathrm{TiO}_{2}$ NPs in the liver after oral exposure. Overall, no hepatotoxic effects were observed following oral gavage since the dosing did not elicit neither acute phase response nor genotoxicity in the liver. This indicates that the secondary oral exposure caused by swallowing a portion of lung-deposited particles did not contribute to the observed adverse effects. In general, larger dose or repeated oral exposure were needed to evoke the toxic effect observed in the other studies $[26,45,46]$.

$\mathrm{CB}$ is a well characterized carbonaceous nanomaterial and very potent ROS generator [22, 47, 48]. Exposure to CB NPs has been shown to induce oxidative DNA damage, increased levels of DNA strand breaks [21, 49] as well as mutagenicity in vivo and in vitro $[22,50]$. The mutation spectrum observed in vitro is consistent with being caused by oxidative DNA damage [47]. The aforementioned studies are in a good agreement with the present results, showing that $\mathrm{CB}$ is much more potent in terms of generating $\mathrm{ROS}$ than $\mathrm{TiO}_{2}$ and $\mathrm{CeO}_{2}$ NPs. Moreover, CB NPs contain very low levels of organic impurities $[22,51,52]$ that excludes the hypothesis that CB-induced genotoxicity is caused by polycyclic aromatic hydrocarbons (PAH) that are absorbed on particles' surface.

\section{Pulmonary acute phase response but no hepatic acute phase response}

In our previous studies $[13,15,40,53,54]$ we demonstrated that $\mathrm{Saa} 3$ was the most upregulated acute phase gene during pulmonary acute phase response and, frequently, the most differentially expressed gene. Saa1 was the most differentially expressed acute phase response gene in the liver [39]. Therefore, Saa3 mRNA expression levels were used as a biomarker for pulmonary acute phase response whereas Saa1 expression was used as a biomarker for hepatic acute phase response [55].

Pulmonary exposure to all three NPs induced similar pulmonary inflammation in terms of neutrophil influx that persisted up to day 28 and long-lasting pulmonary acute phase response that sustained for 180 days. The highest induction of acute phase was observed after day 1 and declined in a time-dependent manner remaining elevated for $\mathrm{TiO}_{2}$ and CB NPs 180 days following exposure. Pulmonary acute phase response was similar for all three particles when compared to the control and no differences between particles were observed. Thus, if the hepatic genotoxicity was caused by systemic circulation of pulmonary inflammatory messengers, then all the assessed NPs would induce hepatic genotoxicity. Instead, hepatic genotoxicity was only observed in $\mathrm{CB}$ exposed groups. Therefore, it is unlikely that circulating cytokines released by pulmonary-mediated inflammation and acute phase response caused the DNA lesions. Moreover, a recent meta-analysis of global transcriptional pattern following pulmonary exposure to $\mathrm{CB}$ and $\mathrm{TiO}_{2} \mathrm{NPs}$ indicated that exposure to $\mathrm{CB}$ and $\mathrm{TiO}_{2}$ induced similar 
changes in pulmonary transcription [56]. Both materials evoked comparable neutrophilic-dominated lung inflammation and similarly altered expression level of many pro-inflammatory genes. In addition, our previous studies indicated that $\mathrm{CB}$ [16] and $\mathrm{TiO}_{2}$ [53] NPs induced similar alterations in the expression profile of selected cytokines genes in the lung tissue. Demonstrated resemblances in the elicited pulmonary response following exposure to $\mathrm{CB}$ and $\mathrm{TiO}_{2}$ should lead to the similar induction level of different secondary mediators that would cause similar level of hepatic DNA SBs in both exposure groups. Instead, we have only observed hepatic genotoxicity in the CB NPs exposed mice, which is an additional evidence of primary genotoxicity caused by the deposited CB NPs rather than by the effects of circulating secondary mediators.

In the present study, we found induction of hepatic acute phase response following lung instillation of $\mathrm{TiO}_{2}$ NPs and $\mathrm{CeO}_{2} \mathrm{NPs}$ and following intravenous injection of $\mathrm{TiO}_{2} \mathrm{NPs}$ that was present at day 1 but has already subsided by the day 28 . Induction of hepatic acute phase response was much weaker and shorter than the pulmonary acute-phase response. Pulmonary exposure to $\mathrm{TiO}_{2}$ increased pulmonary Saa3 expression level 100fold whereas 17.3 fold induction and 9.4 fold induction of hepatic Saa1 was measured after intravenous injection and intratracheal instillation, respectively. No acute phase response was detected in the liver of orally gavaged animals. In addition CB NPs exposure by IV or IT, in contrast to $\mathrm{TiO}_{2}$ and $\mathrm{CeO}_{2}$ did not induce hepatic acute phase response, therefore hepatic acute phase response is also not a likely cause of the observed genotoxicity.

We have previously reported transient or no hepatic acute phase response following pulmonary exposure measured by analysis of the transcriptional changes in liver mRNA of mice exposed to diesel exhaust particles (DEP), CB, multi walled carbon nanotubes [13, 39]. Transient acute phase response in the liver tissue was also reported after pulmonary exposure to $162 \mu \mathrm{g}$ /mouse of $\mathrm{TiO}_{2}$ as reported by [25]. Hepatic acute phase response induced by intravenous injection of gold particles has been reported by Zhang and co-workers [57]. They used Saa reporter mouse model to detect transcriptional activation of hepatic Saa using bioluminescence imaging. Their results demonstrated that among all of the assessed particles $50 \mathrm{~nm}$ Au nanospheres exhibited the highest capacity to induce activation of hepatic Saa. The highest activation was detected $4 \mathrm{~h}$ following intravenous injection. The signal was transient and gradually declined. In the present study lack of detection of hepatic acute phase response after intravenous injection of $\mathrm{CeO}_{2}$ and $\mathrm{CB}$ at all three time points as well as temporary induction of acute phase response in the $\mathrm{TiO}_{2}$ group on day 1 could be explained by the brief and transient nature of acute phase response induction in the liver that causes difficulties in the measurement.

Overall, our results suggest that the observed hepatic DNA damage following IV and IT exposure to CB was caused by the presence of translocated NPs in the liver and their ability to induce oxidative stress rather than by secondary effects of pulmonary inflammation and acute phase response. Particles deposited in the liver are primary accumulated in the Kupffer cells [58]. In the current study, we observed foreign material in sinusoids and in Kupffer cells. Only a small fraction of the liver cells appeared to be directly exposed to the particlegenerated ROS [41]. Apparently, this was sufficient to induce hepatic genotoxicity.

Our results may also imply that inhaled carbon nanoparticles could induce hepatic genotoxicity leading to liver carcinogenesis. It is supported by epidemiological studies showing that exposure to traffic related air pollution is associated with risk of liver cancer $[59,60]$. The International Agency for Research on Cancer (IARC) has classified CB NPs as possibly carcinogenic to humans [61]. It can be speculated that the presence of CB NPs in the liver may, in a long-time perspective, contribute to the onset of cancer.

\section{Conclusions}

Pulmonary exposure to three different NPs, $\mathrm{TiO}_{2}, \mathrm{CeO}_{2}$ and $\mathrm{CB}$ induced long lasting pulmonary inflammation and acute phase response. Indications of translocation to the liver were found for all three NPs. However, only CB dosed by IT and IV induced hepatic genotoxicity. Therefore, our findings indicate that hepatic DNA strand breaks following pulmonary exposure to $\mathrm{CB}$ are likely caused by direct effects of CB NPs that translocate from lung to liver rather than being caused by inflammatory or acute phase responses. Furthermore, the lack of particle translocation, inflammation and acute phase response following oral exposure to NPs suggest that the secondary oral exposure following pulmonary clearance of inhaled particles does not contribute to the observed hepatic genotoxicity.

\section{Additional files}

Additional file 1: Pulmonary Saa3 mRNA expression level following intratracheal instillation of $162 \mu \mathrm{g}$ of $\mathrm{TiO}_{2}, \mathrm{CeO}_{2}$ or CB NPs 1, 28 and 180 days post-exposure. (DOCX $14 \mathrm{~kb}$ )

Additional file 2: Hepatic Saa1 mRNA expression level following intratracheal instillation, intravenous injection and oral gavage of $162 \mu \mathrm{g}$ of $\mathrm{TiO}_{2}, \mathrm{CeO}_{2}$ or CB NPs 1, 28 and 180 days post-exposure. (DOCX $15 \mathrm{~kb}$ )

\section{Abbreviations}

\%TDNA: \% of the DNA in the comet tail; BAL: Bronchoalveolar lavage; BFM: Brightfield microscopy; $\mathrm{CB}$ : Carbon clack; $\mathrm{CeO}_{2}$ : Cerium oxide; DLS: Dynamic light scattering; DNA SBs: DNA strand breaks; EDFM: Enhanced darkfield microscopy; ICP-MS: Inductively coupled plasma mass spectrometry; 
IL-1: Interleukin 1; IL-6: Interleukin 6; IT: Intratracheal; IV: Intravenous; NPs: Nanoparticles; PO: Per oral; RNS: Reactive nitrogen species; ROS: Reactive oxygen species; RT-PCR: Reverse transcription polymerase chain reaction; SAA: Serum amyloid $\mathrm{A}_{;} \mathrm{TiO}_{2}$ : Titanium dioxide; TL: Tail length; TNFa: Tumor necrosis factor a

\section{Acknowledgements}

We gratefully acknowledge Erik H. Larsen for his invaluable contribution in the study designing. The authors would also like to thank Annette Landin, Maja Danielsen, Sarah G. Simonsen, Michael Guldbrandsen, Lourdes M. Pedersen, Elzbieta Christiansen, Anne-Karin Asp, Anne Abildtrup for excellent technical assistance.

\section{Funding}

The project was supported by the Danish Centre for Nanosafety (grant no. 20110092173-3) from the Danish Working Environment Research Foundation.

\section{Availability of data and materials}

All data generated or analyzed during this study are included in this published article (and its supplementary information files).

\section{Authors' contributions}

JM, GRH, KL, AM, ATS, UV contributed to the project idea and design. JM carried out exposures and animal study, real-time RT-PCR, comet assay and statistical analysis of all data. TB provided BFM and EDFM images. NRJ contributed to the animal exposure. NRJ and IEKW carried out ROS assay. JM, TB, GRH, NRJ, IEKW, KL, AM, ATS, UV contributed to the writing of the manuscript, read and approved the final manuscript.

\section{Ethics approval}

The mice study was conducted in the agreement with the Danish Anima Experimental Inspectorate under the Ministry of Justice (Permission 2012-15-2934-00089 (6) and the Technical University of Denmark's animal welfare protocol.

\section{Consent for publication}

Not applicable.

\section{Competing interests}

All authors declare that they have no competing interests.

\section{Publisher's Note}

Springer Nature remains neutral with regard to jurisdictional claims in published maps and institutional affiliations.

\section{Author details}

${ }^{1}$ Technical University of Denmark, National Food Institute, Lyngby, Denmark. ${ }^{2}$ The National Research Centre for the Working Environment, Lersø Parkallé 105, DK-2100 Copenhagen $\varnothing$, Denmark. ${ }^{3}$ Department of Micro- and Nanotechnology, Technical University of Denmark, Kongens Lyngby, Denmark.

Received: 16 August 2017 Accepted: 15 December 2017

Published online: 03 January 2018

\section{References}

1. Stone V, Miller MR, Clift MJD, Elder A, Mills NL, Moller P, et al. Nanomaterials vs ambient ultrafine particles: an opportunity to exchange toxicology knowledge. Environ Health Perspect. 2017;125(10):106002.

2. Oberdörster G, Oberdörster E, Oberdörster J. Nanotoxicology: an emerging discipline evolving from studies of ultrafine particles. Environ Health Perspect. 2005;113:823-39.

3. Geiser M, Kreyling WG. Deposition and biokinetics of inhaled nanoparticles. Part. Fibre Toxicol. 2010;7:2

4. Kreyling WG, Semmler-Behnke M, Takenaka S, Möller W. Differences in the biokinetics of inhaled nano-versus micrometer-sized particles. Acc Chem Res. 2013:46:714-22.

5. Fröhlich E, Salar-Behzadi S. Toxicological assessment of inhaled nanoparticles: role of in vivo, ex vivo, in vitro, and in Silico studies. Int J Mol Sci. 2014;15:4795-822.
6. Paranjpe M, Muller-Goymann CC. Nanoparticle-mediated pulmonary drug delivery: a review. Int J Mol Sci. 2014;15:5852-73.

7. Kreyling WG, Holzwarth U, Haberl N, Kozempel J, Wenk A, Hirn S, et al. Quantitative biokinetics of titanium dioxide nanoparticles after intratracheal instillation in rats: part 3. Nanotoxicology. 2017;11(4):454-64.

8. Sadauskas E, Jacobsen NR, Danscher G, Stoltenberg M, Vogel U, Larsen A, et al. Biodistribution of gold nanoparticles in mouse lung following intratracheal instillation. Chem Cent J. 2009:3:16

9. Takenaka S, Karg E, Kreyling WG, Lentner B, Möller W, Behnke-Semmler M, et al. Distribution pattern of inhaled ultrafine gold particles in the rat lung. Inhal Toxicol. 2006;18:733-40.

10. Semmler M, Seitz J, Erbe F, Mayer P, Heyder J, Oberdörster G, et al. Longterm clearance kinetics of inhaled ultrafine insoluble iridium particles from the rat lung, including transient translocation into secondary organs. Inhal Toxicol. 2004:16:453-9.

11. Kreyling WG, Semmler M, Erbe F, Mayer P, Takenaka S, Schulz H, et al. Translocation of ultrafine insoluble iridium particles from lung epithelium to Extrapulmonary organs is size dependent but very low. J Toxicol Environ Heal PartA. 2002;65:1513-30.

12. Oberdörster G, Sharp Z, Atudorei V, Elder A, Gelein R, Lunts A, et al. Extrapulmonary translocation of ultrafine carbon particles following whole-body inhalation exposure of rats. J Toxicol Environ Heal Part A. 2002;65:1531-43.

13. Saber AT, Lamson JS, Jacobsen NR, Ravn-Haren G, Hougaard KS, Nyendi AN, et al. Particle-induced pulmonary acute phase response correlates with Neutrophil influx linking inhaled particles and cardiovascular risk. PLoS One. 2013:8:1-10.

14. Bourdon JA, Saber AT, Jacobsen NR, Jensen KA, Madsen AM, Lamson JS, et al. Carbon black nanoparticle instillation induces sustained inflammation and genotoxicity in mouse lung and liver. Part. Fibre Toxicol. 2012;9:5.

15. Halappanavar S, Jackson P, Williams A, Jensen KA, Hougaard KS, Vogel UB, et al. Pulmonary response to surface-CoatedNanotitanium dioxide particles includes induction of acute phase response genes, inflammatory cascades, and changes inMicroRNAs: AToxicogenomic study. Environ. Mol. 2011;52:425-39.

16. Jackson P, Hougaard KS, Vogel U, Wu D, Casavant L, Williams A, et al. Exposure of pregnant mice to carbon black by intratracheal instillation: Toxicogenomic effects in dams and offspring. Mutat Res - Genet Toxicol Environ Mutagen. 2012;745:73-83.

17. Husain M, Kyjovska ZO, Bourdon-Lacombe J, Saber AT, Jensen KA, Jacobsen $\mathrm{NR}$, et al. Carbon black nanoparticles induce biphasic gene expression changes associated with inflammatory responses in the lungs of C57BL/6 mice following a single intratracheal instillation. Toxicol Appl Pharmacol. 2015;289:573-88.

18. Bengtson S, Knudsen KB, Kyjovska ZO, Berthing T, Skaug V, Levin M, et al. Differences in inflammation and acute phase response but similar genotoxicity in mice following pulmonary exposure to graphene oxide and reduced graphene oxide. PLoS One. 2017;12:1-25.

19. Schins RPF, Knaapen AM. Genotoxicity of poorly soluble particles. Inhal Toxicol. 2007;19(Suppl 1):189-98.

20. Saber AT, Mortensen A, Szarek J, Koponen IK, Levin M, Jacobsen NR, et al. Epoxy composite dusts with and without carbon nanotubes cause similar pulmonary responses, but differences in liver histology in mice following pulmonary deposition. Part. Fibre Toxicol. 2016;13:37.

21. Jacobsen NR, Pojana G, White P, Moller P, Cohn CA, Korsholm KS, et al. Genotoxicity, Cytotoxicity, and reactive oxygen species induced by singlewalled carbon Nanotubes and C60 fullerenes in the FE1-MutaTM mouse lung epithelial cells. Environ Mol. 2008;49:476-87.

22. Jacobsen NR, Saber AT, White P, Moller P, POjana G, Vogel U, et al. Increased mutant frequency by carbon black, but not quartz, in the lacZ and cll transgenes of muta mouse lung epithelial cells. Environ Mol Mutagen. 2007:48:451-61.

23. Shukla RK, Kumar A, Vallabani NVS, Pandey AK, Dhawan A. Titanium dioxide nanoparticle-induced oxidative stress triggers DNA damage and hepatic injury in mice. Nanomedicine (Lond). 2014;9:1423-34.

24. Kermanizadeh A, Gaiser BK, Hutchison GR, Stone V. An in vitro liver modelassessing oxidative stress and genotoxicity following exposure of hepatocytes to a panel of engineered nanomaterials. Part Fibre Toxicol. 2012;9:28.

25. Wallin $\mathrm{H}$, Kyjovska ZO, Poulsen SS, Jacobsen NR, Saber AT, Bengtson S, et al Surface modification does not influence the genotoxic and inflammatory effects of $\mathrm{TiO} 2$ nanoparticles after pulmonary exposure by instillation in mice. Mutagenesis. 2017;32(1):47-57. 
26. Kumari M, Kumari SI, Kamal SSK, Grover P. Genotoxicity assessment of cerium oxide nanoparticles in female Wistar rats after acute oral exposure. Mutat Res - Genet Toxicol Environ Mutagen. 2014;775:7-19.

27. Auffan M, Rose J, Orsiere T, De Meo M, Thill A, Zeyons O, et al. CeO2 nanoparticles induce DNA damage towards human dermal fibroblasts in vitro. Nanotoxicology. 2009;3:161-71.

28. Zhang R, Dai Y, Zhang X, Niu Y, Meng T, Li Y, et al. Reduced pulmonary function and increased pro-inflammatory cytokines in nanoscale carbon black-exposed workers. Part Fibre Toxicol. 2014;11:73.

29. Saber AT, Jensen KA, Jacobsen NR, Birkedal R, Mikkelsen L, Møller P, et al. Inflammatory and genotoxic effects of nanoparticles designed for inclusion in paints and lacquers. Nanotoxicology. 2012;6:453-71.

30. Mikkelsen L, Sheykhzade M, Jensen KA, Saber AT, Jacobsen NR, Vogel U, et al. Modest effect on plaque progression and vasodilatory function in atherosclerosisprone mice exposed to nanosized TiO2. Part. Fibre Toxicol. 2011;8:32.

31. Poulsen SS, Jackson P, Kling K, Knudsen KB, Skaug V, Kyjovska ZO, et al. Multiwalled carbon nanotube physicochemical properties predict pulmonary inflammation and genotoxicity. Nanotoxicology. 2016;10:1263-75.

32. Kyjovska ZO, Jacobsen NR, Saber AT, Bengston S, Jackson P, Wallin H, et al. DNA damage following pulmonary exposure by instillation to low doses of carbon black (Printex 90) nanoparticles in mice. Environ Mol Mutagen. 2015;56:41-9.

33. Schneider CA, Rasband WS, Eliceiri KW. NIH image to ImageJ: 25 years of image analysis. Nat Methods. 2012;9:671-5.

34. Saber AT, Halappanavar S, Folkmann JK, Bornholdt J, Boisen AMZ, Møller P et al. Lack of acute phase response in the livers of mice exposed to diesel exhaust particles or carbon black by inhalation. Part. Fibre Toxicol. 2009;6:12.

35. Jackson P, Pedersen LM, Kyjovska ZO, Jacobsen NR, Saber AT, Hougaard KS, et al. Validation of freezing tissues and cells for analysis of DNA strand break levels by comet assay. Mutagenesis. 2013;28:699-707.

36. Høgsberg T, Jacobsen NR, Clausen PA, Serup J. Black tattoo inks induce reactive oxygen species production correlating with aggregation of pigment nanoparticles and product brand but not with the polycyclic aromatic hydrocarbon content. Exp Dermatol. 2013;22:464-9.

37. Bourdon JA, Saber AT, Halappanavar S, Jackson PA, Wu D, Hougaard KS, et al. Carbon black nanoparticle intratracheal installation results in large and sustained changes in the expression of miR-135b in mouse lung. Environ Mol Mutagen. 2012;53:462-8.

38. Saber AT, Jacobsen NR, Mortensen A, Szarek J, Jackson P, Madsen AM, et al. Nanotitanium dioxide toxicity in mouse lung is reduced in sanding dust from paint. Part. Fibre Toxicol. 2012;9:4.

39. Poulsen SS, Knudsen KB, Jackson P, Weydahl IEK, Saber AT, Wallin H, et al. Multi-walled carbon nanotube-physicochemical properties predict the systemic acute phase response following pulmonary exposure in mice. PLoS One. 2017;12:e0174167.

40. Saber AT, Jacobsen NR, Jackson P, Poulsen SS, Kyjovska ZO, Halappanavar S, et al. Particle-induced pulmonary acute phase response may be the causal link between particle inhalation and cardiovascular disease. Wiley Interdiscip Rev Nanomed Nanobiotechnol. 2014;6:517-31.

41. Jackson P, Hougaard KS, Boisen AMZ, Jacobsen NR, Jensen KA, Møller P, et al. Pulmonary exposure to carbon black by inhalation or instillation in pregnant mice: effects on liver DNA strand breaks in dams and offspring. Nanotoxicology. 2012;6:486-500.

42. Knaapen AM, Borm PJA, Albrecht C, Schins RPF. Inhaled particles and lung cancer. Part a: mechanisms. Int J Cancer. 2004;109:799-809.

43. Kreyling WG, Holzwarth U, Haberl N, Kozempel J, Wenk A, Hirn S, et al. Quantitative biokinetics of titanium dioxide nanoparticles after oral application in rats: part 2. Nanotoxicology. 2017:11(4):443-53.

44. Geraets L, Oomen AG, Krystek P, Jacobsen NR, Wallin H, Laurentie M, et al. Tissue distribution and elimination after oral and intravenous administration of different titanium dioxide nanoparticles in rats. Part. Fibre Toxicol. 2014;11:30.

45. Sycheva LP, Zhurkov VS, lurchenko W, Daugel-Dauge NO, Kovalenko MA, Krivtsova EK, et al. Investigation of genotoxic and cytotoxic effects of microand nanosized titanium dioxide in six organs of mice in vivo. Mutat Res. 2011;726:8-14

46. Trouiller B, Reliene R, Westbrook A, Solaimani P, Schiestl RH. Titanium dioxide nanoparticles induce DNA damage and genetic instability in vivo in mice. Cancer Res. 2009;69:8784-9.

47. Jacobsen NR, White PA, Gingerich J, Moller P, Saber AT, Douglas GR, et al. Mutation spectrum in FE1-MUTA(TM) mouse lung epithelial cells exposed to nanoparticulate carbon black. Environ Mol Mutagen. 2011;52(4):331-7.
48. Hussain S, Boland S, Baeza-Squiban A, Hamel R, Thomassen LCJ, Martens JA, et al. Oxidative stress and proinflammatory effects of carbon black and titanium dioxide nanoparticles: role of particle surface area and internalized amount. Toxicology. 2009;260:142-9.

49. Jacobsen NR, Møller P, Jensen KA, Vogel U, Ladefoged O, Loft S, et al. Lung inflammation and genotoxicity following pulmonary exposure to nanoparticles in ApoE-/- mice. Part. Fibre Toxicol. 2009;6:2.

50. Driscoll KE, Carter JM, Howard BW, Hassenbein DG, Pepelko W, Baggs RB, et al. Pulmonary inflammatory, Chemokine, and mutagenic responses in rats after subchronic inhalation of carbon black. Toxicol Appl Pharmacol. 1996; 136:372-80.

51. Jackson P, Vogel U, Wallin H, Hougaard KS. Prenatal exposure to carbon black (printex 90): effects on sexual development and neurofunction. Basic Clin Pharmacol Toxicol. 2011;109:434-7.

52. Borm PJA, Robbins D, Haubold S, Kuhlbusch T, Fissan H, Donaldson $\mathrm{K}$, et al. The potential risks of nanomaterials: a review carried out for ECETOC. Part. Fibre Toxicol. 2006;3:11

53. Husain M, Saber AT, Guo C, Jacobsen NR, Jensen KA, Yauk CL, et al. Pulmonary instillation of low doses of titanium dioxide nanoparticles in mice leads to particle retention and gene expression changes in the absence of inflammation. Toxicol Appl Pharmacol. 2013;269:250-62.

54. Jackson P, Halappanavar S, Hougaard KS, Williams A, Madsen AM, Lamson $J S$, et al. Maternal inhalation of surface-coated nanosized titanium dioxide (UV-titan) in C57BL/6 mice: effects in prenatally exposed offspring on hepatic DNA damage and gene expression. Nanotoxicology. 2013;7:85-96.

55. Poulsen SS, Saber AT, Mortensen A, Szarek J, Wu D, Williams A, et al. Changes in cholesterol homeostasis and acute phase response link pulmonary exposure to multi-walled carbon nanotubes to risk of cardiovascular disease. Toxicol Appl Pharmacol. 2015;283:210-22.

56. Nikota J, Williams A, Yauk CL, Wallin H, Vogel U, Halappanavar S. Meta-analysis of transcriptomic responses as a means to identify pulmonary disease outcomes for engineered nanomaterials. Part. Fibre Toxicol. 2016;13:25.

57. Zhang Y, Zhou Q, Yan S, Zhang N, Zhao M, Ma C, et al. Non-invasive imaging serum Amyloid a activation through the NF-KB signal pathway upon gold nanostructure exposure. Small 2016;3270-82.

58. Sadauskas $E$, Wallin $H$, Stoltenberg M, Vogel U, Doering P, Larsen A, et al. Kupffer cells are central in the removal of nanoparticles from the organism. Part Fibre Toxicol. 2007:4:10.

59. Soll-Johanning $\mathrm{H}$, Bach $\mathrm{E}$, Olsen $\mathrm{JH}$, Tüchsen $\mathrm{F}$. Cancer incidence in urban bus drivers and tramway employees: a retrospective cohort study. Occup Environ Med. 1998;55:594-8.

60. Raaschou-Nielsen O, Andersen ZJ, Hvidberg M, Jensen SS, Ketzel M, Sorensen $M$, et al. Air pollution from traffic and cancer incidence: a Danish cohort study. Env Heal. 2011;10:67.

61. Baan R, Straif K, Grosse Y, Secretan B, El Ghissassi F, Cogliano V, et al. Carcinogenicity of carbon black, titanium dioxide, and talc. Lancet Oncol. 2006;7(4):295-6.

62. Levin M, Rojas E, Vanhala E, Vippola M, Liguori B, Kling K, et al. Influence of relative humidity and physical load during storage on dustiness of inorganic nanomaterials: implications for testing and risk assessment. J Nanopart Res. 2015;17:337.

63. Halappanavar S, Saber AT, Decan N, Jensen KA, Wu D, Jacobsen NR, et al. Transcriptional profiling identifies physicochemical properties of nanomaterials that are determinants of the in vivo pulmonary response. Environ Mol Mutagen. 2015;56:245-64.

64. Saber AT, Bornholdt J, Dybdahl M, Sharma AK, Loft S, Vogel U, et al. Tumor necrosis factor is not required for particle-induced genotoxicity and pulmonary inflammation. Arch Toxicol. 2005;79:177-82.

65. Lide DR. CRC handbook of chemistry and physics. 84th ed; 2004. 